\title{
WKŁAD ŚRODOWISKA POZNAŃSKO-GNIEŹNIEŃSKIEGO W BADANIA NAD LITERATURA WCZESNOCHRZEŚCIJAŃSKĄ
}

Problem: „Wkład środowiska poznańsko-gnieźnieńskiego w badania nad literaturą wczesnochrześcijańską" jest niezmiernie trudny. Trudność ta wynika przede wszystkim $z$ tego, iż można lub nawet należy rozważać go w trzech aspektach:

a) Można mówić o środowisku wielkopolskim pojętym geograficznie z silnym centrum, jakim jest Poznań;

b) Dalej można mówić o środowisku poznańsko-gnieźnieńskim biorąc pod uwagę dwa ośrodki, a mianowicie Poznań i Gniezno: wokół nich koncentrowało się bowiem życie intelektualne. Połączenie dwóch archidiecezji: poznańskiej i gnieźnieńskiej unią personalną, która trwała do 1953 r. sprawiło, że można mówić o jednym środowisku: poznańskognieźnieńskim. Chociaż w Poznaniu był uniwersytet, jednak bez Wydziału Teologicznego, to Gniezno z Poznaniem wiązały seminaria duchowne, w których kształcili się razem przyszli kapłani z obu archidiecezji pod kierunkiem tych samych profesorów. Ci z kolei nie tylko pochodzili z terenów jednej lub drugiej archidiecezji, ale również oddziaływali na nie w sposób niezaprzeczalny.

c) Wreszcie można mówić o środowisku Wydziału Teologicznego Uniwersytetu im. Adama Mickiewicza, czyli o tych wszystkich ośrodkach seminaryjnych i zakonnych oraz instytutach dla świeckich, które są z nim związane od 1. grudnia 1998 roku.

Aby ująć w sposób całościowy i zadowalający wszystkich zaproponowany temat, przedstawię go w trzech punktach. Najpierw ukażę naukową działalność osób zajmujących się patrologią i literaturą wczesnochrześcijańską na terenie Wielkopolski, następnie skupię się na najważniejszych seriach wydawniczych i podręcznikach patrologii związanych ze środowiskiem poznańskim, i w końcu spróbuję wskazać miejsce patrologii, jakie zajmuje na Wydziale Teologicznym Uniwersytetu im. Adama Mickiewicza w Poznaniu. 


\section{NAUKOWA DZIAŁALNOSĆ PATROLOGÓW NA TERENIE WIELKOPOLSKI}

Ze środowiskiem wielkopolskim związana jest przede wszystkim działalność osób, którym zawdzięczamy rozwój patrologiి, zarówno po pierwszej, jak i po drugiej wojnie światowej. Pomimo to, że Uniwersytet Poznański nie posiadał Wydziału Teologicznego, o czym wspomniałem już wcześniej, niektórzy jego profesorowie stali się badaczami literatury wczesnochrześcijańskiej i przyczynili się w znacznym stopniu do propagowania myśli patrystycznej nie tylko na swoim terenie, ale także w Polsce i w świecie. Na szczególną uwagę zasługują tu trzy postacie, a mianowicie profesor Jan Sajdak, ks. profesor Józef Nowacki oraz ks. docent Bronisław Gładysz. Pozwolę sobie krótko scharakteryzować ich działalność i wkład w badania nad literaturą wczesnochrześcijańską.

a) Jan Sajdak. Urodził się 22 lutego 1882 r. w Burzynie w ówczesnym powiecie tarnowskim. Na Wydziale Filozoficznym Uniwersytetu Jagiellońskiego studiował filologię klasyczną, archeologię klasyczną i historię filozofii, zwłaszcza greckiej oraz historię literatury polskiej. Ostatnie lata studiów poświęcił patrologii, szczególnie Ojcom Kościoła z IV wieku. Doktorat obronił na Uniwersytecie Jagiellońskim w Krakowie. Tam też przeprowadził habilitację. Wykładał na Wydziale Filozoficznym Uniwersytetu Jagiellońskiego filologię klasyczną, a także na Uniwersytecie Lwowskim, gdzie uzyskał tytuł profesora nadzwyczajnego filologii klasycznej. Należy jeszcze wspomnieć o stypendium, które otrzymał w 1910 r., dzięki któremu prowadził badania nad rękopisami w bibliotekach włoskich, szwajcarskich, paryskich, londyńskich, berlińskich, w Oxfordzie oraz w Wiedniu i Monachium. Tam też uczęszczał na wykłady i seminaria.

Kolejnym etapem jego naukowej działalności była praca na Uniwersytecie Poznańskim, gdzie mianowano go profesorem zwyczajnym filologii klasycznej. Pracę na tej uczelni rozpoczął od zorganizowania biblioteki seminaryjnej filologii klasycznej. Zakupił zbiory między innymi po zmarłych profesorach Schenklu z Wiednia i Klussmannie z Lipska. Dzięki temu stworzył największą w Polsce bibliotekę tej specjalności. Później poszerzył ją jeszcze o patrystykę i bizantynistykę, które zostały wyposażone w najnowsze wydawnictwa $\mathrm{z}$ tego zakresu. Profesor Sajdak jest twórcą tzw. poznańskiej szkoły filologicznej. W ciągu długich lat pracy na Uniwersytecie Poznańskim pełnił liczne funkcje uniwersyteckie: był delegatem Rady Wydziału Filozoficznego do senatu uczelni, dziekanem Wydziału Filozoficznego, w roku akademickim 1931/32 pełnił funkcję rektora Uniwersytetu Poznańskiego, rok później był jego prorektorem, był także prezesem Komisji Egzaminacyjnej dla Kandydatów na Nauczycieli Szkół Średnich i Komisji Egzaminów Państwowych w Poznaniu na Nauczycieli Szkół Średnich, prezesem Komisji Egzaminów Magisterskich na Wydziale 
Humanistycznym. Jako jeden z inicjatorów protestu brzeskiego został przeniesiony w 1934 r. w stan przymusowego spoczynku. Profesor Sajdak postarał się jednak o przywrócenie mu prawa wykładania na Uniwersytecie Jagiellońskim i przeniósł je na Uniwersytet Poznański, gdzie prowadził dalszą bezpłatną działalność dydaktyczną (bezpłatną, ponieważ formalnym powodem jego zwolnienia z Uniwersytetu Poznańskiego były trudności budżetowe uczelni). W Poznaniu założył Collegium Marianum, którym kierował do czasu wybuchu wojny, a także zakład wychowawczy złożony ze szkoły powszechnej i gimnazjów męskiego i żeńskiego.

W środowisku poznańskim głównym przedmiotem badań Jana Sajdaka była literatura bizantyjsko-grecka. Jest autorem wielu prac z tej dziedziny, m.in. Spicilegium Geometreum ${ }^{1}$, krytyczne wydanie tekstów poety Jana Kyriotesa Geometresa: Hymni in SS. Deiparam (Posnaniae 1931), zarys Literatury

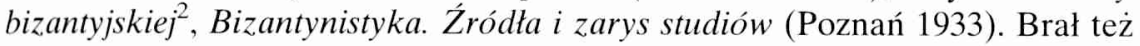
udział w kilku międzynarodowych kongresach bizantynistów. Przedmiotem zainteresowań Profesora Sajdaka stała się również literatura grecka i rzymska. I w tej dziedzinie jest autorem kilku drobnych prac, m.in.: Franciszek Zabłocki jako tłumacz Horacego (Poznań 1928). Należy tu jeszcze wspomnieć o artykułach: Papiez. Wielki i Pius XI jako uczony, które zamieścił w pracy zbiorowej Piusowi XI. Wielkiemu Papieżowi w hotdzie (Poznań 1939), wydanej przez Naczelny Instytut Akcji Katolickiej ${ }^{3}$ oraz zestawienie Bibliografii prac i rozpraw naukowych ks. Achillesa Ratti ${ }^{4}$.

W latach 1920-1921 redagował wraz z Tadeuszem Sinką „Eos” i przez wiele lat był członkiem komitetu redakcyjnego tego pisma. Swoje prace zamieszczał nie tylko w czasopismach polskich, ale także w fachowych czasopismach zagranicznych, zwłaszcza niemieckojęzycznych.

Z inspiracji profesora Sajdaka poznański księgarz i wydawca Jan Jachowski rozpoczął wydawanie w 1923 r. pierwszej polskiej patrystycznej serii thumaczeniowej: „Pisma Ojców Kościoła”; on również był pierwszym redaktorem naczelnym tej serii i prowadził ją aż do 1949 roku. Przełożył dla niej Oktawiusza Minucjusza Feliksa (t. 2, Poznań 1925), oraz Apologetyka Tertuliana (t. 20, Poznań 1949). Należy tu również wspomnieć, że w 1936 r. na specjalnej audiencji wręczył papieżowi Piusowi XI 18 pierwszych wydanych tomów serii „Pisma Ojców Kościoła”.

Oprócz działalności przekładowej w serii „Pisma Ojców Kościoła” Jan Sajdak jest autorem kilku prac z zakresu patrologii, jak np. obszernej monografii: Kwintus Septimiusz Florens Tertulian. Czasy - życie - dzieła (Poznań

'Por. „Eos” 32(1929) 191-198.

${ }^{2}$ Por. Wielka Literatura Powszechna, IV, Warszawa 1933, 681-760 (Literatura bizantyńska).

${ }^{3}$ Por. Piusowi XI. Wielkiemu papieżowi w hołdzie, Poznań 1939, s. 31-40 (Papiez Wielki), s. 59-61 (Pius XI jako uczony).

${ }^{4}$ Por. tamże, s. 61-64. 
1949, ss. 553). Dzieło to powstało w Tuchowie pod Tarnowem, gdzie J. Sajdak przebywał w czasie wojny i korzystał z tamtejszej biblioteki. Wracając do czasów pracy naukowej na Uniwersytecie Jagiellońskim należy wspomnieć o doktoracie, który obronił na podstawie pracy: Quaestiones Nazianzenicae. Pars prima: Quae ratio inter Gregorium Nazianzenum et Maximum Cynicum intercedat ${ }^{5}$. Grzegorz z Nazjanzu pozostał też przedmiotem jego zainteresowań. Uniwersytecki mistrz Sajdaka prof. Leon Sternbach powierzył mu opracowanie komentatorów i scholiastów Grzegorza. Dzięki temu powstały następujące prace związane z Grzegorzem z Nazjanzu: De Gregorio Nazianzeno posteriorum rhetorum, grammaticorum, lexicographorum fonte ${ }^{6}$, Historia critica scholiastarum et commentatorum Gregorii Nazianzeni I (Kraków 1914), De Gregorio Nazianzeno poetarum christianorum fonte (Kraków 1917), Die Scholiasten der Reden des Gregor von Nazianz ${ }^{7}$, Nazianzenica ${ }^{8}$, Rękopisy św. Grzegorza z Nazyanzu $w$ bibliotekach szwajcarskich ${ }^{9}$. Sajdak nie zdążył jednak przygotować monografii oraz krytycznego wydania scholiastów Grzegorza, ponieważ materiały do tego opracowania zaginęły w Poznaniu w 1939 roku. Inne prace z dziedziny patrologii to wykład inauguracyjny na otwarcie roku akademickiego 1931/32 wygłoszony w Auli Uniwersytetu Poznańskiego na temat: Pedagogiczne poglady Grzegorza z Nazjanzu (Poznań 1933) oraz referat Studia patrystyczne w Polsce (Poznań 1931) wygłoszony w Poznaniu w 1931 roku.

Działalność Sajdaka na płaszczyźnie patrologii związana jest również z jego członkostwem w Komisji Filologicznej AU. Pełnił także funkcję sekretarza wchodzącego w skład tej Komisji Komitetu do Wydawnictwa Greckich Ojców Kościoła IV wieku. Był czlonkiem PAU, Towarzystwa Naukowego we Lwowie, Poznańskiego Towarzystwa Przyjaciół Nauk, Bizantynistyki Polskiej Akademii Nauk; należał również do Zarządu Towarzystwa Literackiego im. A. Mickiewicza. Swój pracowity żywot prof. Jan Sajdak zakończył w Poznaniu dnia 22 kwietnia 1967 roku $^{10}$.

b) Ks. Józef Nowacki. Ze środowiskiem poznańsko-gnieźnieńskim związany był także ks. profesor Józef Nowacki. Urodził się 19 września $1893 \mathrm{r}$. w Mroczy na Krajnie. Studia teologiczne odbył w Seminarium Duchownym

5 Por. „Eos” 15(1909) 18-48.

6 Por. „Eos” 16(1910) 94-99, 18(1912) 1-30.

7 Por. „Byzantinische Zeitschrift” 30(1930) 268-274.

8 Por. „Eos” 15(1909) 122-129, 16(1910) 87-93.

9 Por. „Eos” 17(1911) 193-198; zob. tegoż: Anonymi Oxoniensis Lexicon in orationes Gregorii Nazianzeni, w: Symbolae grammaticae in honorem Joannis Rozwadowski, I, Cracoviae 1927, 153-177; tenże, Biblioteki patrystycznych rękopisów greckich na Wschodzie, „Przegląd Polski” 48(1914) t. 192, 106-119.

10 Wiadomości biograficzne opracowane na podstawie: R. Skręt, Sajdak Jan, w: Polski Słownik Biograficzny, t. 34, Wrocław-Kraków-Warszawa 1992-1993, s. 332-334. 
w Poznaniu i w Gnieźnie w latach 1913-1917. Po otrzymaniu święceń kapłańskich rozpoczął specjalizację na uniwersytecie w Münster, gdzìe przez dwa lata studiował historię Kościoła i filologię klasyczną. Na Uniwersytecie Poznańskim nie było Wydziału Teologicznego, stąd w latach 1919-1921 studiował historię i filologię klasyczną. Tutaj też otrzymał dyplom w zakresie filologii klasycznej i klasyczno-orientalnej, a w 1926 r. uzyskał doktorat z teologii na uniwersytecie Jana Kazimierza we Lwowie. W 1938 r. przeprowadził we Lwowie habilitację i został docentem. Już w 1927 r. Prymas August Hlond mianował ks. J. Nowackiego profesorem nadzwyczajnym historii Kościoła i patrologii w Arcybiskupim Seminarium Duchownym w Poznaniu; później otrzymał nominację na profesora zwyczajnego. Wykładał w Gnieźnie i w Poznaniu historię Kościoła aż do 1961 r., a patrologię w Poznaniu do 1964 r., natomiast w Gnieźnie do 1953 r., gdy nastąpił rozdział seminariów po wcześniejszym rozdziale obu archidiecezji.

Głównym jego zainteresowaniem naukowym była historia Kościoła. Jest autorem dwutomowego dzieła Dzieje archidiecezji poznańskiej (Poznań 1959, 1964) oraz wielu innych prac z zakresu historii, zwłaszcza Kościoła w Wielkopolsce $^{11}$. Jako wykładowca patrologii chciał, aby kojarzyła się ona bardziej z historią antycznej myśli chrześcijańskiej niż ze zbiorem opracowań literackich użytecznych tylko dla apologety, kaznodziei czy wychowawcy. Z jego inspiracji wykłady dla roczników młodszych w Gnieźnie (I i II rocznik) prowadził ks. Andrzej Wronka, a rok przed wojną ks. Michał Kozal. Czytano wówczas po lacinie Passio S.S. Perpetuae et Felicitatis oraz po grecku teksty liturgiczne Jana Chryzostoma. Sam natomiast prowadził cały czas w Poznaniu wykłady z patrologii. Po wojnie wykładał również w Gnieźnie ${ }^{12}$. Jego uczeń, ks. profesor Szczepan Pieszczoch, tak wspomina spotkania ze swoim profesorem patrologii: „Byliśmy zaszokowani jego erudycją historyczną. Zaciążyła ona nieco na przejrzystości wykładu, ale dała nam wyobrażenie o gigantycznym wysiłku myślowym ludzi tamtych czasów i to nie tylko wykształconych biskupów, kapłanów, mnichów a także laików, nie tylko filozofów i retorów, ale także prostych ludzi, głęboko wierzących i miłujących Zbawiciela. Klimat tego zaangażowania w apologiach, polemikach, był nieraz bardzo gorący. Przeciwnik-heretyk był czasem zbyt mocno traktowany, jako domniemany uczeń diabła. Wykłady Nowackiego więcej niż sam podręcznik pomagały nam zbliżyć się do zrozumienia tamtych ludzi i czasów"13.

${ }^{11}$ Por. szczegółowy wykaz jego prac: M. Banaszak, Nowacki Józef (1895-1964), w: Stownik Polskich Teologów Katolickich 1918-1981, red. L. Grzebień, t. 6, Warszawa 1983, 553-556.

${ }^{12}$ Por. Sz. Pieszczoch, Patrologia w Wielkopolsce, szczególnie w Gnieźnie, przed i po II wojnie światowej na tle sytuacji ogólnopolskiej, „Studia Gnesnensia” 11(1997) 341.

${ }^{13}$ Sz. Pieszczoch, Ksiądz Józef Nowacki jako patrolog, w: Ecclesia Posnaniensis opuscula Mariano Banaszak Septuagenario dedicata, Universitatis Mickiewiczianae Facultas Theologica, Posnaniae 1998, s. 271-272. 
Mówiąc o wkładzie księdza Nowackiego w badania nad literaturą wczesnochrześcijańską w środowisku gnieźnieńsko-poznańskim należy wspomnieć przede wszystkim o dokonanym przez niego przekładzie podręcznika G. Rauschena Zarys patrologii, który ukazał się nakładem Księgarni św. Wojciecha w Poznaniu w 1929 roku $^{14}$. Szerzej o tej pozycji będzie mowa przy omawianiu podręczników patrologii, które ukazały się staraniem patrologów wielkopolskich. Ksiądz profesor Józef Nowacki zmarł 28 kwietnia 1964 roku w Poznaniu.

c) Ks. Bronisław Gładysz. Należy tu wspomnieć jeszcze o badaczu łaciny średniowiecznej, docencie Uniwersytetu Poznańskiego, księdzu Bronisławie Gładyszu. Urodzony 3 września 1892 r. w Sierakowie w województwie poznańskim ukończył gimnazjum klasyczne w Gnieźnie, kształcił się w Seminarium Duchownym w Poznaniu i Gnieźnie. Po otrzymaniu święceń kapłańskich był kapelanem wojskowym, a później proboszczem parafii św. Antoniego w Starołęce. W tym czasie studiował na Uniwersytecie Poznańskim, gdzie uzyskał tytuł doktora filozofii, a po habilitacji został zatwierdzony w charakterze docenta Uniwersytetu Poznańskiego w zakresie średniowiecznej literatury łacińskiej. Prowadził działalność dydaktyczną a także referował swoje prace w Komisjach Teologicznej i Filozoficznej Poznańskiego Towarzystwa Przyjaciół Nauk. Ogłosił drukiem ponad 40 rozpraw oraz liczne streszczenia, sprawozdania i recenzje. Jego publikacje dotyczą przeważnie poetów chrześcijańskich: Seduliusza oraz Wenancjusza Fortunata. Opracowania księdza Gładysza związane były z zagadnieniami hymnografii, rymotwórstwa oraz łacińskiego dramatu średniowiecznego i hagiografii ${ }^{15}$. Wśród najważniejszych publikacji można wymienić: Dogmatyczne teksty w poetyckich utworach Seduliusza. Studium z historii dogmatów V wieku (Poznań 1930), Rzym w poezji Seduliusza ${ }^{16}$, Święty Augustyn u kolebki hymnografii tacińskiej ${ }^{17}$, De extremis quibus Seduliana carmina ornantur verborum syllabis inter se consonantibus (Leopoli 1931), Pierwiastki poklasyczne w traktacie Bedy „De arte metrica”, Konstantyn Wielki we wspótczesnej mu poezji ${ }^{19}$, Cassiodore et l'organisation de l'Ecole Medievale ${ }^{20}$, Dzisiejsza hymnodia kościelna w swym historycznym

${ }^{14}$ Por. Zarys patrologii. Pisma Ojców Kościoła i nauka w nich zawarta. Z 8 i 9 nowo opracowanego wydania niemieckiego przełożył i uzupełnil ks. J. Nowacki, Poznań 1929, ss. XI + 450.

15 Por. J. Dziech, Gtadysz Bronisław Hieronim, w: Polski Stownik Biograficzny, t. 8, Wrocław-Kraków-Warszawa 1959-1960, s. 7; zob. także M. Wolniewicz, Gładysz Bronisław Hieronim, w: Stownik Polskich Teologów Katolickich 1918-1981, red. L. Grzebień, t. 5, Warszawa 1983, s. 449453 (pełny wykaz bibliografii).

${ }^{16}$ Por. „Kwartalnik Klasyczny” 3(1929) 73-84.

17 Por. „Przegląd Teologiczny” 11(1930) 371-398.

18 Por. „Sprawozdania Poznańskiego Towarzystwa Przyjaciół Nauk” 7(1933) 3-5.

19 Por. CT 18(1937) 63-100.

${ }^{20}$ Por. CT 17(1936) 15-69. 
rozwoju ${ }^{21}$. Przed drugą wojną światową, w latach trzydziestych, ukazało się również w „Mysterium Christi” i w „Kurierze Poznańskim” kilka drobnych artykułów na temat hymnów Wenancjusza Fortunata.

Chociaż cała działalność naukowa księdza B. Gładysza nie jest związana ściśle tylko z Ojcami Kościoła, to jednak można w niej dostrzec zajmowanie się pewnymi pracami i badaniem literatury wczesnochrześcijańskiej. Należy podkreślić, że wydał drukiem ponad 40 rozpraw, prócz licznych przyczynków, streszczeń, sprawozdań i recenzji.

Ksiądz Bronisław Gladysz aresztowany 18 lipca 1941 r. przez Gestapo, był więziony najpierw w Poznaniu, potem we Wronkach, Zwickau, Rawiczu i Gusen, gdzie zginął 19 czerwca 1943 roku.

\section{SERIE WYDAWNICZE I PODRĘCZNIKI}

Niezaprzeczalną zasługą środowiska poznańskiego w badaniach nad literaturą wczesnochrześcijańską jest z pewnością znana seria wydawnicza pod nazwą „Pisma Ojców Kościoła” zainicjowana w 1924 r. przez profesora Uniwersytetu Poznańskiego Jana Sajdaka. Ukazał się wówczas nakładem Księgarni Uniwersyteckiej pierwszy jej tom, który zawierał tłumaczenie Pism Ojców Apostolskich. Do II wojny światowej, a więc do 1939 r., ukazało się we wspomnianej serii w ciągu 15 lat 20 tomów przekładów pism literatury wczesnochrześcijańskiej. Wśród nich były m.in., oprócz wspomnianych Pism Ojców Apostolskich, Oktawiusz Minucjusza Feliksa, Historia kościelna Euzebiusza z Cezarei, dwie Apologie i Dialog z żydem Tryfonem św. Justyna, Wyznania, Pisma katechetyczne i Państwo Boże św. Augustyna, Listy św. Grzegorza z Nazjanzu, Kazania wybrane św. Leona Wielkiego, niektóre pisma apologetów greckich II wieku, kilka pism św. Cypriana z Kartaginy oraz Mowy św. Ambrożego z Mediolanu. Wszystkie z tych przekładów zawierały wstępy i komentarze. Należy zaznaczyć, że z niektórych, chociaż wydane były przed wojną, korzystamy do dzisiaj, chociażby z Historii kościelnej Euzebiusza z Cezarei, która doczekała się w 1993 r. tylko przedruku przez Wydawnictwo Apostolstwa Modlitwy w Krakowie.

Po zakończeniu drugiej wojny światowej seria „Pisma Ojców Kościoła” wznowiła swoją działalność, która trwała do 1971 roku. Nie była ona jednak już tak płodna, jak w okresie międzywojennym. Przez.26 lat wydano bowiem tylko siedem tomów. Wpłynęły zapewne na to trudności wydawnicze, z jakimi borykały się wszystkie wydawnictwa kościelne w okresie trwającego w Polsce komunizmu. Jako pierwszy ukazał się po wojnie Apologetyk Tertuliana, a także

${ }^{21}$ Por. AK 18(1932) t. 30, 366-377; zob. też: Święty Augustyn a poezja, „Kurier Poznański” 22(1927) nr 389, s. 7. 
Księga reguty pasterskiej św. Grzegorza Wielkiego, dialog $O$ kapłaństwie św. Jana Chryzostoma, Mowy św. Leona Wielkiego, Wybór pism dogmatycznych św. Ambrożego oraz $O$ Trójcy Świętej i Traktaty o tasce św. Augustyna. Podobnie jak tłumaczenia przedwojenne, te również miały wstępy i komentarze.

W sumie, od 1924 do 1971 r. wydano 27 tomów w serii „Pisma Ojców Kościoła”. Tomy od 1 do 23 wydawane były przez Księgarnię Uniwersytecką w Poznaniu, a wydawcą był Jan Jachowski, natomiast tomy następne od 24 do 27 kontynuowane były przez Księgarnię św. Wojciecha w Poznaniu.

Wśród thumaczy serii „Pisma Ojców Kościoła” powtarzają się przede wszystkim trzy nazwiska: ks. Jan Czuj, który przełożył 8 tomów, dalej ks. Arkadiusz Lisiecki - 3 tomy oraz Jan Sajdak - 2 tomy.

Nie chciałbym oceniać doboru tłumaczonych dzieł, a tym bardziej ich poziomu. Na pewno na czasy przedwojenne było to osiągnięcie, które zasługuje na uznanie. Należy zaznaczyć, że nie było wówczas takich możliwości, jakie posiadamy dzisiaj. Pomimo to niektóre wydania posiadają dobre indeksy, których sporządzenie z pewnością nie należało do łatwych. Mimo, że „Pisma Ojców Kościoła” stanowiły jedyną serię przedwojenną, która zawierała tłumaczenia dzieł niektórych Ojców Kościoła i pisarzy wczesnochrześcijańskich, to jednak jej popularność nie była zbyt duża. Spis prenumeratorów, który sporządził przedwojenny wydawca Jan Jachowski liczył do 1937 r. zaledwie 198 nazwisk, natomiast lista abonentów z 1939 r. dodana do tomu 21, liczyła tylko 178 pozycji. Na tej liście było 10 biskupów, 10 seminariów duchownych, 14 domów zakonnych i 25 osób świeckich ${ }^{22}$.

Ze środowiskiem poznańskim związana jest jeszcze jedna seria wydawnicza, a mianowicie „Starożytna Myśl Chrześcijańska” pod redakcją ojca profesora Jana Marii Szymusiaka SJ, zainaugurowana przez Wydawnictwo św. Wojciecha. Ukazały się w niej jednak tylko dwa tomy: pierwszy w 1965 roku: Grzegorz Teolog. U źródet chrześcijańskiej myśli IV wieku autorstwa ojca Jana M. Szymusiaka, drugi w 1971 roku: Słownik wczesnochrześcijańskiego piśmiennictwa o. Jana M. Szymusiaka i ks. Marka Starowieyskiego. Nie była to seria, w której ukazywały się tłumaczenia pism Ojców. Książka Grzegorz Teolog zawiera co prawda przekład niektórych Mów (2, 7, 8, 15, 18, 25, 26, 37, 42) i Poematów św. Grzegorza z Nazjanzu, ale należy raczej do opracowań teologicznych. Stownik wczesnochrześcijańskiego piśmiennictwa jest natomiast zestawem biografii świadków tradycji chrześcijańskiej od czasów apostolskich do chwili pierwszej stabilizacji świata europejskiego po wstrząsach wędrówki ludów na Zachodzie (VIII wiek), a na Wschodzie do II Soboru Nicejskiego (787 r.).

${ }^{22}$ Por. Pieszczoch, Patrologia w Wielkopolsce, art. cyt., s. 337; zob. również: S. Longosz, "Pisma Starochrześcijańskich Pisarzy" na tle innych polskich serii patrystycznych, SACh 11(1995) 61-74. 
Zasługą środowiska poznańsko-gnieźnieńskiego jest również wydanie paru podręczników patrologii. Pierwszym było wspomniane już tłumaczenie ks. Józefa Nowackiego na język polski Grundriss der Patrologie Gerharda Rauschena z poprawionego i uzupełnionego przez J. Wittiga. Przetlumaczył je z jego ósmego i dziewiątego wydania z 1926 roku. Wspomniany podręcznik ukazał się, jak wspominaliśmy wyżej, w roku 1929 nakładem Księgarni św. Wojciecha w Poznaniu pod tytułem: Zarys patrologii. Pisma Ojców Kościoła i nauka w nich zawarta.

Po II wojnie światowej ukazał się wydany w 1964 r. przez Księgarnię św. Wojciecha w Poznaniu podręcznik patrologii autorstwa ks. Szczepana Pieszczocha pt. Patrologia. Wprowadzenie w studium Ojców Kościoła. Składał się on z trzech podstawowych części: „Prolegomena patrystyczne” (część I), które zawierają wprowadzenie teologiczne, ze szczególnym uwzględnieniem problemu tradycji, „Zarys patrologii” (część II), gdzie omówione zostały początki literatury patrystycznej oraz rozwój teologii patrystycznej aż do Izydora z Sewilli i Jana Damasceńskiego zakończony krótkim zarysem historii teologii popatrystycznej, a całość tej drugiej części zaopatrzona była w wybory bardzo zwięzłych tekstów. Część III zatytułowana: „Pomoce do dalszego samodzielnego studium Ojców Kościoła” zawiera bibliografię głównych pozycji literatury patrystycznej oraz ówczesne aktualności patrologiczne. Podręcznik ks. profesora Sz. Pieszczocha używany był przez długie lata jako pomoc w poznawaniu Ojców Kościoła i pisarzy kościelnych okresu patrystycznego, zwłaszcza w seminariach duchownych. Należy zaznaczyć, że w okresie powojennym, oprócz Patrologii ks. Jana Czuja, wydanej również w Poznaniu w 1953 i 1954 r., nie było innego podręcznika do tej dyscypliny w języku polskim. W $1994 \mathrm{r}$. ks. Sz. Pieszczoch przepracował swoją pierwszą Patrologię i wydał ją w dwóch tomach w gnieźnieńskim wydawnictwie „Gaudentinum”. Pierwsza część zatytułowana: „Działalność Ojców” zawiera prezentację dorobku ważniejszych autorów antyku chrześcijańskiego do VIII wieku. Całość zakończona została materiałami uzupełniającymi, wśród których na szczególną uwagę zasługuje tutaj Polskojezyczna bibliografia antyku chrześcijańskiego za lata 1900-1993 i Polskie wydawnicze serie patrystyczne opracowane przez ks. dra Stanisława Longosza (ss. 201-280 + I-XXIV). Drugi tom tego podręcznika: „Ojcowie mówią" zawiera wybrane teksty autorów omówionych w części pierwszej. Trzecie wydanie podręcznika ks. Sz. Pieszczocha Patrologia, tym razem w jednej części (ss. 414), miało miejsce w 1998 roku.

\section{WYDZIAEY TEOLOGICZNE}

Wkład środowiska poznańsko-gnieźnieńskiego w badania nad literaturą wczesnochrześcijańską należy wiązać także z Wydziałami Teologicznymi. Pa- 
trologia znalazła bowiem swoje właściwe miejsce na Papieskim Wydziale Teologicznym w Poznaniu, który został założony w 1969 roku. Związały się z nim najpierw seminaria diecezjalne: Gniezno i Gdańsk, a potem Szczecin i Koszalin oraz zakonne: Oblaci, Misjonarze św. Rodziny i Karmelici Bosi, a także Instytuty dla świeckich, działające w Gnieźnie, Bydgoszczy i Koszalinie. W ramach Papieskiego Wydziału Teologicznego staraniem ks. profesora Bogdana Częsza istniał Instytut Teologii Patrystycznej i Starożytności Chrześcijańskiej, którego kierownikiem był jego założyciel. Powstanie Papieskiego Wydziału Teologicznego wiązało się zatem $\mathrm{z}$ podniesieniem poziomu naukowego, $\mathrm{w}$ tym również z patrologii. Uzyskano bowiem dzięki temu prawo nadawania stopni naukowych. W ciągu 29 lat istnienia Papieskiego Wydziału Teologicznego powstały liczne magisteria z patrologii, prace licencjackie a także doktorskie. Dla zobrazowania prężności naukowej tego środowiska chciałbym podkreślić znaczącą liczbę prac, które zostały napisane do tej pory z patrologii pod kierunkiem ks. profesora B. Częsza: 3 doktoraty, 10 licencjatów i ponad 90 magisteriów. Prace magisterskie powstawały i nadal powstają również w Gnieźnie i Bydgoszczy na seminarium naukowym $\mathrm{z}$ antyku chrześcijańskiego pod kierunkiem ks. dra Ludwika Gładyszewskiego oraz z patrologii pod kierunkiem ks. profesora Szczepana Pieszczocha (do przejścia na emeryturę), a od 1994 roku u ks. dra Bogdana Czyżewskiego. Należy również wspomnieć o pracach magisterskich, które pisane są w innych Seminariach Duchownych diecezjalnych i zakonnych, kiedyś związanych z Papieskim Wydziałem Teologicznym w Poznaniu, a które obecnie stanowią sekcje Wydziału Teologicznego Uniwersytetu im. A. Mickiewicza w Poznaniu.

Dnia 1 grudnia 1998 r. utworzono Wydział Teologiczny Uniwersytetu im. Adama Mickiewicza w Poznaniu, w ramach którego działa Zakład Teologii Patrystycznej. Liczy on obecnie dwóch profesorów (ks. prof. dr hab. Bogdan Częsz - teologia patrystyczna, ks. prof. dr hab. Antoni Swoboda - starożytna literatura chrześcijańska), 8 adiunktów oraz jednego starszego wykładowcę.

Osoby związane poprzednio z Papieskim Wydziałem Teologicznym, a obecnie z Wydziałem Teologicznym Uniwersytetu im. Adama Mickiewicza, prowadzą seminaria naukowe $\mathrm{z}$ patrologii i antyku chrześcijańskiego, zarówno dla duchownych i kleryków, jak i dla świeckich, ukazują się ich publikacje w formie książek i licznych artykułów, w których podejmują tłumaczenia dzieł Ojców Kościoła i badania nad literaturą wczesnochrześcijańską. Świadczy to o tym, że patrologia w Wielkopolsce nie należy do zapomnianych dyscyplin, co więcej, zdajemy sobie sprawę z tego, że musimy kontynuować dorobek naszych wielkich poprzedników, którzy dysponując zupełnie innymi środkami i możliwościami tak wiele uczynili dla rozpowszechnienia i przybliżenia bogatego dorobku pierwszych wieków Kościoła. 


\section{LA PARTICIPATION DU MILIEU SCIENTIFIQUE DE POZNAŃ ET GNIEZNO DANS LES RECHERCHES SUR LA LITTÉRATURE PALÉOCHRETIENNE}

(Résumé)

Le sujet proposé est étudié sur les trois aspects. Tout d'abord on présente l'activité scientifiques des chercheurs qui s'occupaient de patristique dans la région de Wielkopolska: le professeur Jan Sajdak (1882-1967) - l'Université de Poznań, le professeur Józef Nowacki (1893-1964) - le Grand Séminaire de Poznań et de Gniezno, et aussi le professeur Bronisław Gładysz (1892-1943) - l'Université de Poznań. Tous les trois contribuaient à développement de la patristique non seulement en Wielkopolska, mais aussi en Pologne toute entière car ils ont travaillé sur les oeuvres des Pères de l'Eglise.

Ensuite on présente les éditions en Wielkopolska. La plus importante était la série intitulée: „Les écrits de Pères de l'Eglise”, éditée à Poznań de 1924 à 1971 (27 tomes) sous la direction de Jan Sajdak. On a édité aussi les manuels de la patristique. C'était une traduction polonaise d'une oeuvre allemande de Gerhard Rauschen intitulée „Grundriss des Patrologie” qui a étè faite par Józef Nowacki. Il faut nommé aussi les trois manuels de patrologie, surtout pour les seminaristes, du professeur Szczepan Pieszczoch.

Enfin on présente la Faculté Théologique où on peut faire les études patristique. En 1969 on a fondé la Faculté Papale Théologique à Poznań et avec lui se sont attachés les séminaires de differents diocèses: Gniezno, Gdańsk, Szczecin, Koszalin, Obra, Kazimierz Biskupi, et aussi les instituts pour les laics: à Gniezno, Bydgoszcz et Koszalin. De 1er décembre 1998 on a fondé la Faculté Téologique d'Université d'Adam Mickiewicz à Poznań qui contient aussi l'Institut de Théologie Patristique. Sous la direction des enseignants de cet Institut on prépare des thèses, des maîtrises et des licences. L'Institut de Théologie Patristique élargit les recherches et les publications sur l'antiquité chrétienne. 